\title{
The Role Of Brand Image As Mediating Variable In The Influence Of Price And Promotion On Buying Interest (Study Case On Hyundai Electric Car)
}

\author{
Soegeng Wahyoedi ${ }^{1}$, Saparso ${ }^{2}$, Miki Effendi ${ }^{3}$ \\ 1,2,3 Faculty of Economics and Business, Krida Wacana Christian University, Jakarta, Indonesia \\ *Corresponding Author: \\ Email: mikieffendi@gmail.com
}

\begin{abstract}
The development of environmentally friendly vehicles is currently a global trend among car manufacturers. This is in addition to being triggered by regulations from countries that have committed in the 2016 Paris agreement to reduce greenhouse gas emissions and save fossil-based fuels that will run out, considering that fossil fuels are a type of non-renewable natural resource. For this reason, the global automotive industry has begun to produce electric cars, which are referred to as renewable energy sources, and to reduce carbon emissions. Because this electric car is a new product, researchers are interested in knowing how someone is buying an electric car. One of the elements that influence a person's buying interest is the price. Besides the price, buying interest is also influenced by promotion. With the proper promotion, it can encourage people to buy. Therefore, this study wanted to examine the effect of price and promotion on buying interest mediated by brand image. Sampling using non-probability sampling and purposive sampling with criteria for the general public living in Jabodetabek who already have a car and can buy a car. Data analysis in this study used a Structural Equation Modeling (SEM) approach based on Partial Least Square. This study found that price, promotion, and brand image had a significant and positive effect on buying interest. Brand image mediates significantly and positively the relationship between price and promotion on purchase intention.
\end{abstract}

Keywords: Price, Promotion, Brand Image, Purchase Intention, Electric Car.

\section{INTRODUCTION}

Transportation is the movement of objects from one place to another and has become a significant need for humans to facilitate humans in carrying out daily activities. The car is one of the land transportation tools that are often used today and uses fossil fuels. The long-standing use of fossil fuels has created new problems for the environment. Fossil fuels are non-renewable natural resources, and according to research from the Kitami Institute of Technology, Hokkaido, Japan, fossil fuels will run out in 2050. The solution to this problem has made countries decide to start abandoning cars with fossil fuels and start encouraging car manufacturers to produce electric cars, which are referred to as renewable energy sources.

Fig 1. Electric Vehicle Market Growth

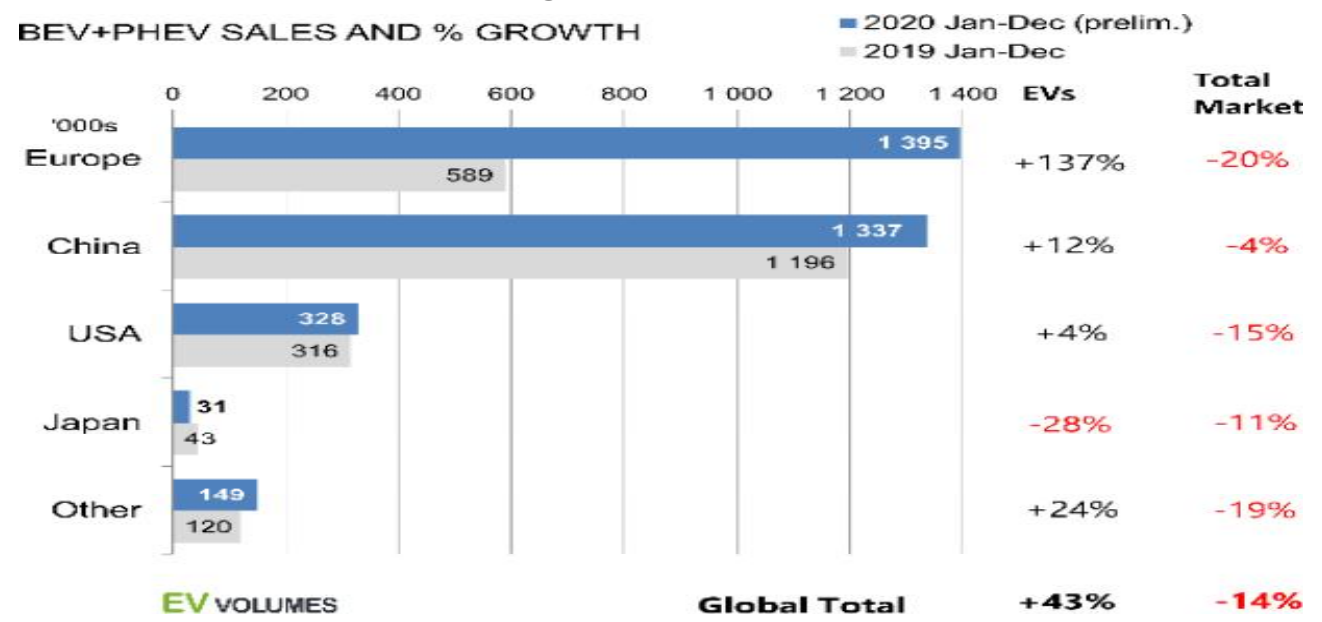

Source: EV-Volumes - The Electric Vehicle World Sales Database (2021) 
The picture above shows the phenomenon of global passenger car sales in 2020 down by $14 \%$ compared to 2019 , but inversely proportional to electric car sales, which grew by $43 \%$ in 2020 . The Indonesian government is committed to encouraging the development of the electric car industry to replace materialbased cars as if Fossil fuel. The government's seriousness in encouraging the development of electric cars, namely by issuing Presidential Regulation (Perpres) number 55 of 2019 concerning the Acceleration of the Battery-Based Electric Motor Vehicle Program (KBLBB) for Road Transportation. This Presidential Regulation is a form of government attention to the importance of sustainable transportation in the future.

Table 1. Electric Car Wholesales Distribution Data (January-December 2020)

\begin{tabular}{|c|c|c|c|c|c|c|c|c|c|c|c|c|c|c|c|}
\hline \multirow{2}{*}{ BRAND } & \multirow{2}{*}{ TYPE MODEL } & \multirow{2}{*}{ FUEL } & \multicolumn{12}{|c|}{ MONTH } & \multirow{2}{*}{$\begin{array}{c}\text { TOTAL } \\
2020 \\
\end{array}$} \\
\hline & & & JAN & FEB & MAR & APR I & MAY & JUN & JUL & AUG & SEP & OCT & NOV & DEC & \\
\hline \multirow{3}{*}{ Hyundai } & Ioniq EV Prime & 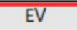 & "- & "- & 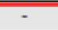 & "- & "- & 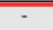 & $=$ & - & "- & 5 & 4 & $\overline{c 5}$ & 14 \\
\hline & Ioniq EV Signature & $\mathrm{EV}$ & - & - & & - & - & - & & & - & 29 & 11 & 5 & 45 \\
\hline & Kana EV & EV & - & - & - & - & - & - & . & - & - & 20 & 18 & - & 38 \\
\hline Lexus & UX 300e & EV &. & $=$ & - & $=$ & $=$ & - & $=$ & $=$ & 1 & $=$ & $=$ & - & 1 \\
\hline \multirow{2}{*}{ BMW } & 276218 & Hybrid & - & - & - & - & - & - & - & - & 1 & - & - & - & 1 \\
\hline & $8 P 6213120$ & Hybrid & - & - & 1 & - & $=$ & - & 2 & $=$ & - & 1 & 1 & - & 5 \\
\hline \multirow[t]{2}{*}{ Nissan } & Kicks E-Power & Hybrid & - & - & - & - & - & - & - & - & 43 & 37 & 43 & 30 & 153 \\
\hline & C-HR $1.8 \mathrm{~A} / \mathrm{T}$ Hybrid & Hybrid & 3 & 18 & 21 & 4 & - & 17 & 28 & 9 & 2 & 9 & 6 & 9 & 126 \\
\hline \multirow{3}{*}{ Toyota } & Carolla Cross $1.8 \mathrm{~A} / \mathrm{T}$ Hybrid & Hybrid & - & - & - & - & - & - & - & 112 & 182 & 135 & 86 & 137 & 652 \\
\hline & All New Corolla Altis 1.8 Hybrid & Hybrid & 3 & 6 & 9 & - & - & - & 6 & 4 & - & 3 & 5 & 5 & 41 \\
\hline & All New Camry 2.5 Hybrid & Hybrid & 9 & 30 & 31 & 6 & - & 7 & 20 & 11 & 5 & 10 & 1 & - & 130 \\
\hline Mitsubishi & Outlander PHEV & PHEV & 2 & 2 & 1 & - & - & - & - & - & 1 & - & - & - & 6 \\
\hline
\end{tabular}

Source: Gaikindo (2021)

Currently, not many car manufacturers in Indonesia have developed battery-based electric cars. The table above shows sales of electric cars for the January-December 2020 period, which are categorized as pure electric cars (BEV) and will be produced in Indonesia based on Presidential Regulation No. 55 in 2019 only the Hyundai brand.The prospect of electric cars is indeed exciting, so it is necessary to know how the response and buying interest of the Indonesian people towards electric cars. One of the elements that influence buying interest is promotion; proper promotion can encourage people to buy. Companies with good quality products will not be able to market their products well if they do not have an excellent promotional strategy (Winoto, 2020). Tjiptono (2019) states that promotion is one of the factors that determine the success of a product, no matter how good the product is, if it is not marketed with the proper promotion, consumers will not be sure that the product is helpful for them, which in the end the promotion can be to provide information, directly and indirectly.

Can indirectly influence or persuade, and as a reminder that consumers will never forget the company's brands and products.Another element influencing a person's buying interest is price, where price plays an essential role in consumer purchasing decisions. The right pricing strategy can be a determinant of the success of a product and company in the short and long term; pricing is too expensive even though Good quality is not necessarily reachable by the company's target market; in other words, customer value will be low. On the other hand, if the pricing is too low or cheap, consumers may perceive that the quality of the product is not good (Tjiptono, 2019). The price element is a determining factor for many market demands (Winoto, 2020).From the description above, it raises the curiosity of researchers about how much Indonesian people's buying interest is in electric cars, especially Hyundai electric cars, so the title of this research is "The Mediation Role of Brand Image in the Effect of Price and Promotion on Buying Interest (Study on Electric Cars). Hyundai)". The formulation of the problem in this study are:

1. Does price affect buying interest?

2. Does promotion affect buying interest?

3. Does brand image affect buying interest?

4. Does the price affect the brand image?

5. Does promotion affect the brand image?

6. Does brand image mediate the effect of price on purchase intention?

7. Does brand image mediate the effect of promotion on purchase intention?

\section{Price}

Price is a value labeled for goods and services used as a reference and can be measured by an amount of money. According to Amanda et al. (2021), price is the only part of the marketing mix that 
generates revenue for the organization. Price is an essential element in marketing strategy and mutually supports or relates to all variables in the marketing mix. However, the price is the only element that directly affects profits and can generate revenue for sales, while the other elements are only cost elements (Aussari, 2014). The company must carry the strategy for placing prices on products with proper considerations and calculations of production costs and profit margins to be taken. Of course, it must be adjusted to the selected market segment because this can be one of the causes of whether the market can accept the products offered by the company or not, or quite the opposite. Meanwhile, Tjiptono (2019) states that price is a monetary measure or as a medium of exchange for goods and services that can be paid for so that there is an exchange of ownership rights or utilization of specific goods and services. Therefore, consumers become very critical when they feel that the money they spend on an item does not match their expectations for the benefits they receive. Kotler and Armstrong (2018) suggest four indicators characterize a price: price affordability, price suitability with product quality, price suitability with benefits, and price according to ability or price competitiveness.

\section{Promotion}

Promotion is one element of the marketing mix that supports the company's activities in marketing products and services in the form of effective communication to have a positive influence on consumers so that they are interested in trying and buying and using these products and services. Lupiyoadi (2014) states that promotional activities carried out by companies other than as a means of communication between companies and consumers are also used to persuade consumers to be interested in the products and services offered by the company consumers decide to make a purchase. Promotion can be said as a bridge that connects consumers with producers or companies, and the proper promotional communication carried out by the company will make the product or service more quickly known or known by consumers. Kotler and Keller (2016) introduced four promotion indicators: promotional messages, promotional media, promotion time, and frequency of promotions. In the competitive era, promotion strategies are also essential to attract the attention of the consumer to attract them to by-product or service, and it can be done in the form of special prices, discounts, or other soft selling provided by the company (Wahyoedi et al., 2021).

\section{Brand Image}

The survival of a company or product is primarily determined by the image built by the company. An image cannot be built in a short time, but it takes quite a long time, and there are costs to be incurred. Generally, a brand image automatically arises in the minds of consumers when they are watching or hearing a specific brand; the image created can be negative or positive depending on the extent of the positioning of the brand. Alma (2016) defines brand image as a logo or sign that reflects a personality for certain goods and services, and it can only be in the form of information or descriptions, images or symbols, or a combination of the two. Therefore, every company must care about the design of their products so that consumers easily recognize them. Keller (2013) suggests that several indicators can form a brand image: brand identity, brand personality, brand association, brand attitude and behavior, and brand benefits and competence.

\section{Purchase Intention}

Purchase Intention is a type of decision-making that studies customers' reasons for buying a particular brand (Amitay et al., 2020). Buying interest is a tendency of consumer attitudes who have curiosity and interest in a product or service but have not yet entered the stage of making a purchase decision. Buying interest tends to be influenced by consumer behavior, knowledge, or the amount of positive information received; this encourages consumer attitudes to find out about the advantages and disadvantages of a product or service if it is judged to be able to meet the needs they want, it will indirectly lead to desire. Strong enough to own the product or service. Kotler and Keller (2016) state that buying interest is a consumer behavior or action before making a purchasing decision on a product or service and how likely it is to make consumers switch to other brands or products. There are several indicators put forward by Ferdinand (2014) to measure buying interest, namely: transactional interest, referential interest, preferential interest, and exploratory interest. 
This research has the following conceptual framework:

Fig 2. Conceptual Framework Model

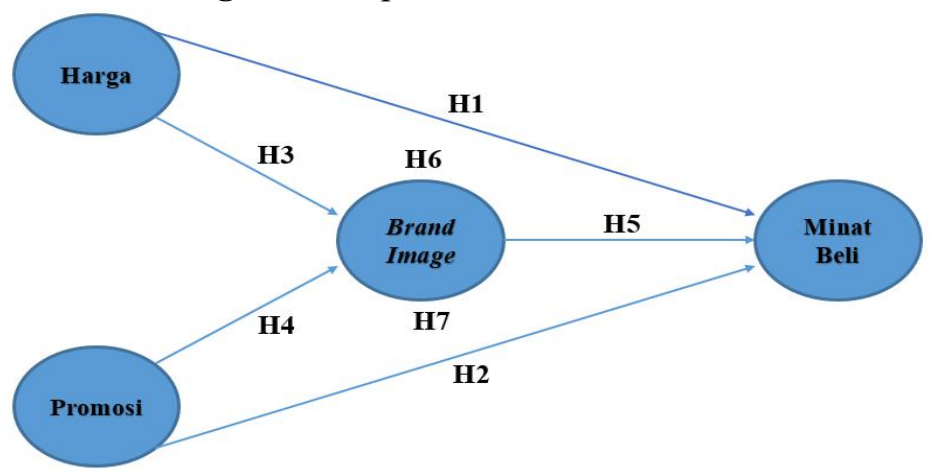

H1: Price has a positive effect on buying interest.

H2: Promotion has a positive effect on buying interest.

H3: Price has a positive effect on brand image.

H4: Promotion has a positive effect on brand image.

H5: Brand image has a positive effect on buying interest.

H6: Price has a positive effect on buying interest mediated by brand image.

H7: Promotion has a positive effect on buying interest mediated by brand image.

\section{RESEARCH METHODOLOGY}

This research is a quantitative research using primary data and instruments in a questionnaire or questionnaire on a Likert scale. The population of this research is the general public who live in Jabodetabek, whose number is unknown. This study uses non-probability sampling as a sampling technique, and purposive sampling is used to determine the sample, namely the general public who live in Greater Jakarta who already has a car and can buy a car. Determination of the number of samples based on Hair et al. (2010) states that for a population whose size is unknown, it is recommended to use a sample size of 5-10 from the number of indicators used in the study. In this study, there are 17 indicators, so the minimum number of samples used is $5 \times 17=85$ respondents and rounded up to 100 respondents. Data analysis using PLS-SEM approach with SmartPLS 3.3 software. There are three stages of analysis that can be used in PLS-SEM, namely:

1. The first stage, by analyzing the measurement model (outer model), namely the measurement model that connects the manifest (indicator) with its latent variables (Ghozali and Latan, 2015). The measurement model with reflective indicators uses a validity and reliability test approach.

- Test the validity of the instrument, including convergent validity, average variance extracted (AVE), and discriminant validity measured by three steps, namely using the Fornell-Larcker Criterion method, cross-loading value, and the Heterotrait-Monotrait (HTMT) method.

- Instrument Reliability Test is a unidimensionality test of the model using composite reliability and Cronbach's alpha values.

2. The second stage, by analyzing the structural model (inner model), namely the structural model that connects the latent variables. Using four measurements, namely: R-Square (coefficient of determination), Q-Square (prediction relevance), f-Square (effect size), and Goodness of Fit Index (GoF).

3. The third stage, by testing the hypothesis.

\section{RESULT AND DISCUSSION}

\section{Validity and Reliability Test (Outer Model)}

A validity test is used to test the instrument's level of accuracy and accuracy that should be measured. An instrument is valid if it has a loading factor greater than or equal to 0.70 (Hair et al., 2017). Reliability indicates the level of accuracy of the measurement tool. The value of an instrument is said to be reliable if it has a Cronbach's alpha value and composite reliability > 0.7 (Ghozali and Latan, 2015). 
Fig 3. Research Construct

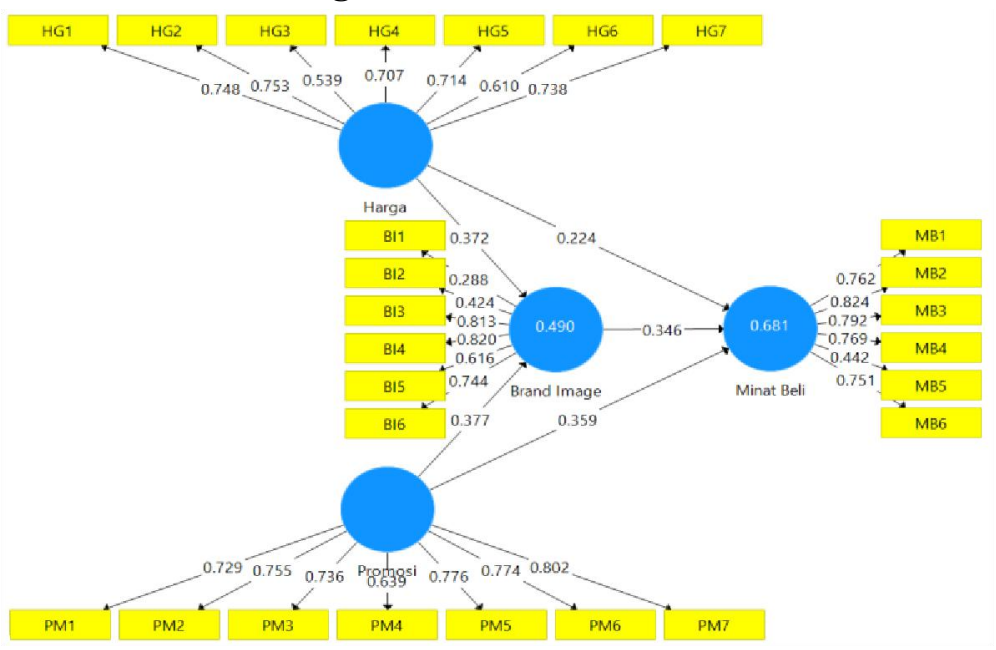

In the picture above, the price construct is measured by seven indicators, seven indicators measure the promotion construct, six indicators measure the brand image construct, and six indicators measure the purchase interest construct. It can be seen that several indicators were found to be invalid because they had a loading factor value of $<0.7$. Invalid indicators are excluded as variables measuring indicators, which must be considered at this stage, namely the value of convergent validity, discriminant validity, composite reliability, and Cronbach alpha.Convergent validity is used to determine instrument items that can be used as indicators of all latent variables. The results of this test are measured based on the value of the loading factor (outer loading) of the construct indicator.

Table 2. Outer Loading Value

\begin{tabular}{cccc|}
\hline Konstruk & Indikator & Loading Factor & AVE \\
\hline \hline \multirow{5}{*}{ Harga } & HG1 & 0,801 & \\
& HG2 & 0,777 & \multirow{6}{*}{0,561} \\
& HG4 & 0,708 & \\
& HG5 & 0,719 & \\
& HG7 & 0,737 & \\
& PM1 & 0,748 & 0,593 \\
& PM2 & 0,787 & \\
Promosi & PM3 & 0,733 & \\
& PM5 & 0,773 & 0,715 \\
& PM6 & 0,782 & \\
\hline \multirow{5}{*}{ Brand Image } & PM7 & 0,796 & \\
& BI3 & 0,880 & 0,62 \\
& BI4 & 0,849 & \\
\hline \multirow{5}{*}{ Minat Beli } & BI6 & 0,807 & \\
& MB1 & 0,763 & \\
& MB2 & 0,840 & \\
& MB3 & 0,783 & \\
& MB4 & 0,789 & \\
\hline
\end{tabular}

Sumber: Data Olahan SmartPLS (2021)

In the table above, after adjusting the data by removing all the values on the indicators that are declared ineligible or invalid (loading factor value $<0.7$ ), then the following data has met the parameters with a loading factor value above 0.7 . So it can be concluded that all indicators in this study have a high level of validity and have met convergent validity.Apart from the loading factor value, convergent validity can be analyzed by looking at the Average Variance Extracted (AVE) value. The construct value is declared valid and shows a good measure of convergent validity of the AVE value of each indicator is $>0.5$ (Ghozali and 
Latan, 2015). The table above shows that the AVE value in each construct has exceeded 0.5 , so it can be concluded that there is no convergent validity problem in the model tested in this study.After it was found that there were no problems in the analysis of convergent validity, it was continued with discriminant validity analysis. The first test uses the Fornell-Larcker Criterion method by comparing the AVE value with the correlation value between constructs. If the AVE value is greater than the correlation value between latent variables, then discriminant validity can be considered achieved. The following table shows that all latent variables have AVE values more significant than the other constructs, so it can be concluded that the discriminant validity requirements for all constructs have been met.

Table 3. Fornell-Larcker Criterion Value

\begin{tabular}{lcccc}
\hline \multicolumn{1}{c}{ Konstruk } & Brand Image & Harga & Minat Beli & Promosi \\
\hline \hline Brand Image & $\mathbf{0 , 8 4 6}$ & & & \\
Harga & 0,618 & $\mathbf{0 , 7 4 9}$ & & \\
Minat Beli & 0,682 & 0,730 & $\mathbf{0 , 7 8 7}$ & \\
Promosi & 0,590 & 0,727 & 0,744 & $\mathbf{0 , 7 7 0}$ \\
\hline
\end{tabular}

Sumber: Data Olahan SmartPLS (2021)

The second step in the discriminant validity test is to see the value of the cross-loading. The following table shows the value of the loading factor of HG1 on the price of 0.801 , much greater than the value of the loading factor of HG1 on promotions of 0.582 , of the brand image of 0.413 , and of buying interest of 0.602. Likewise, for several other indicators, there is a correlation that the loading factor value of each item on the construct has a value greater than the cross-loading value, so it can be concluded from the results of the cross-loading analysis that there are no problems with discriminant validity.

Table 4. Cross-Loading Factor

\begin{tabular}{ccccc}
\hline Indikator & Harga & Promosi & Brand Image & Minat Beli \\
\hline HG1 & 0,801 & 0,582 & 0,413 & 0,602 \\
HG2 & 0,777 & 0,516 & 0,393 & 0,569 \\
HG4 & 0,708 & 0,523 & 0,567 & 0,543 \\
HG5 & 0,719 & 0,565 & 0,430 & 0,555 \\
\hline HG7 & 0,737 & 0,532 & 0,498 & 0,457 \\
\hline PM1 & 0,573 & 0,748 & 0,394 & 0,748 \\
\hline PM2 & 0,601 & 0,787 & 0,390 & 0,787 \\
PM3 & 0,562 & 0,733 & 0,477 & 0,733 \\
\hline PM5 & 0,479 & 0,773 & 0,412 & 0,773 \\
\hline PM6 & 0,529 & 0,782 & 0,517 & 0,782 \\
\hline PM7 & 0,602 & 0,796 & 0,528 & 0,796 \\
\hline BI3 & 0,544 & 0,483 & 0,880 & 0,508 \\
BI4 & 0,496 & 0,533 & 0,849 & 0,553 \\
B16 & 0,524 & 0,477 & 0,807 & 0,656 \\
\hline MB1 & 0,470 & 0,505 & 0,501 & 0,763 \\
\hline MB2 & 0,723 & 0,685 & 0,702 & 0,840 \\
MB3 & 0,521 & 0,576 & 0,458 & 0,783 \\
MB4 & 0,589 & 0,575 & 0,405 & 0,789 \\
MB6 & 0,529 & 0,562 & 0,570 & 0,758 \\
\hline
\end{tabular}

Sumber: Data Olahan SmartPLS (2021)

The third step in the discriminant validity test is to use the Heterotrait-Monotrait (HTMT) method. The value of the Heterotrait-Monotrait (HTMT) must be $<0.9$ so that it can be declared to meet the discriminant validity requirements (Henseler et al., 2015). The following table shows that the entire distribution of values is still $<0.9$, so it can be stated that all constructs have met the discriminant validity requirements based on the Heterotrait-Monotrait (HTMT) count. 
Table 5. Heterotrait-Monotrait (HTMT) Value

\begin{tabular}{lcccc}
\hline \multicolumn{1}{c}{ Konstruk } & Brand Image & Harga & Minat Beli & Promosi \\
\hline \hline Brand Image & & & & \\
Harga & 0,765 & & & \\
Minat Beli & 0,807 & 0,869 & & \\
Promosi & 0,707 & 0,869 & 0,861 & \\
\hline
\end{tabular}

Sumber: Data Olahan SmartPLS (2021)

The last test on the outer model is to test the unidimensionality of the model using the values of composite reliability and Cronbach's alpha. The following table shows the value of composite reliability and Cronbach's alpha generated by all constructs $>0.7$, meaning that all constructs have good reliability and no reliability/unidimensionality problems were found in the former model.

Table 6. Composite Reliability and Cronbach's Alpha

\begin{tabular}{lcc}
\hline \multicolumn{1}{c}{ Variabel } & Composite Reliability & Cronbach's Alpha \\
\hline Harga & 0,865 & 0,804 \\
Promosi & 0,897 & 0,862 \\
Brand Image & 0,883 & 0,800 \\
Minat Beli & 0,891 & 0,847 \\
\hline
\end{tabular}

Sumber: Data Olahan SmartPLS (2021)

The conclusion for the analysis of the outer model in this study is that all indicators have met the rules of validity and reliability to be continued with the analysis of the inner model.

\section{Structural Model Analysis (Inner Model)}

The analysis of the inner model is carried out in 4 steps, namely: the R-Square (R2), Q-Square $\left(\mathrm{Q}^{2}\right)$, f-Square $\left(\mathrm{f}^{2}\right)$, and Goodness of Fit (GoF) methods. Chin (1988) explained that the R-Square values of 0.67, 0.33 , and 0.19 were interpreted as strong, moderate, and weak model parameters.

Table 7. R-Square

\begin{tabular}{lcc}
\hline \multicolumn{1}{c}{ Matrix } & R-Square & Keterangan \\
\hline \hline $\begin{array}{l}\text { Harga dan Promosi } \\
\text { terhadap Brand Image }\end{array}$ & 0,424 & Moderat \\
$\begin{array}{l}\text { Brand Image, Harga, Promosi } \\
\text { terhadap Minat Beli }\end{array}$ & 0,678 & Kuat \\
\hline Sumber: Hasil Olahan Data SmartPLS (2021) &
\end{tabular}

The table above shows the effect of price and promotion on a brand image with an R-Square value of 0.424 . All exogenous constructs of price and promotion simultaneously affect brand image by $42.4 \%$, and other factors outside the study influence the remaining 57.6\%. Because the R-Square value is in the range of 0.33 0.67 , the effect of all price and promotion, exogenous constructs on the brand image are in the moderate category. The effect of price, promotion, and brand image on buying interest with an R-Square value of 0.678. All exogenous constructs of price, promotion, and brand image simultaneously affect buying interest by $67.8 \%$, and other factors outside the study influence the remaining $32.2 \%$. Because it has an R-Square value $>0.67$, the influence of all exogenous constructs of price, promotion, and brand image on buying interest is included in the strong model category.The next inner model test is by looking at the Q-Square value. Calculation of the value of Q-Square can use the following formula:

$$
\begin{aligned}
\text { Q-Square }=\mathrm{Q}^{2} & =1-\left(1-\mathrm{R}_{1}^{2}\right)\left(1-\mathrm{R}_{2}^{2}\right) \\
& =1-(1-0,424)(1-0,678) \\
& =1-(0,576)(0,322) \\
& =1-0,185472 \\
& =0,815
\end{aligned}
$$


It can be interpreted that $81.5 \%$ of the variation in the endogenous variable (purchase interest) is explained by the variables used in the model, and other factors outside the model explained $18.5 \%$. This result proves that the model has predictive relevance.The next step in the internal model analysis is to perform the f-square test. Sarstedt et al. (2017) provide criteria for f-Square values of $0.35,0.15$, and 0.02 , interpreted as significant influences, medium effects, and minor effects. For the value of f-Square $<0.02$, it is considered that there is no effect and can be ignored. The following is the value of the f-Square test results.

Table 8. f-Square Value

\begin{tabular}{ccc}
\hline \multicolumn{1}{c}{ Konstruk } & f-Square & Keterangan \\
\hline \hline Harga - Minat Beli & 0,106 & Kecil \\
Promosi - Minat Beli & 0,182 & Medium \\
Brand Image - Minat Beli & 0,151 & Medium \\
Harga - Brand Image & 0,132 & Kecil \\
Promosi - Brand Image & 0,073 & Kecil \\
\hline Sumber: Hasil Olahan Data SmartPLS & $(2021)$ &
\end{tabular}

Sumber: Hasil Olahan Data SmartPLS (2021)

In the table above, there is no significant influence with the criteria $\mathrm{f}$-Square $>0.35$; the medium effect is found on the effect of promotion on buying interest and the influence of brand image on buying interest. In comparison, the effect of price on buying interest, the effect of price on brand image, and the influence of promotion on the brand image are included in the small influence. No f-Square value was found $<0.02$, so no effect was ignored.The last test of the inner model by calculating the GoF value, calculation of GoF value can use the following formula:

$$
\begin{aligned}
\mathrm{GoF} & =\sqrt{\overline{\mathrm{AVE}} \times \overline{\mathrm{R}}^{2}} \\
& =\sqrt{0,622 \times 0,551} \\
& =0,585
\end{aligned}
$$

Tenenhaus (2004) provides an interpretation for small $\mathrm{GoF}=0.1$, moderate $\mathrm{GoF}=0.25$, and large $\mathrm{GoF}=$ 0.38. Based on the results of the GoF calculation, it shows that the level of feasibility of the model in the GoF category is large and robust for making predictions. The results of the R-Square, Q-Square, f-Square, and GoF tests show that the model formed is robust so that the analysis in this study can be continued for further testing, namely hypothesis testing.

\section{Hypothesis Testing}

Hypothesis testing can be analyzed based on the t-statistical and probability or significance value (pvalue) from the bootstrapping results. The hypothesis will be accepted if the t-statistics value is $>1.96$ or the $\mathrm{p}$-value is $<0.05$.

Table 9. Direct and Indirect Effect

\begin{tabular}{lccc}
\hline & Koefisien & t-statistik & p-value \\
\hline Harga -> Minat Beli & 0,285 & 2,966 & 0,003 \\
Promosi -> Minat Beli & 0,365 & 4,438 & 0,000 \\
Harga -> Brand Image & 0,401 & 3,664 & 0,000 \\
Promosi -> Brand Image & 0,298 & 2,820 & 0,005 \\
Brand Image -> Minat Beli & 0,291 & 2,988 & 0,003 \\
Harga -> Brand Image -> Minat Beli & 0,117 & 2,084 & 0,038 \\
Promosi -> Brand Image -> Minat Beli & 0,087 & 2,436 & 0,015 \\
\hline
\end{tabular}

Sumber: Hasil Olahan Data SmartPLS (2021)

There are five direct influence hypotheses tested in this study, namely:

a. H1: Price has a positive effect on buying interest.

In the table above, the coefficient value is positive at 0.285 with a t-statistic value of $2.966>1.96$ and a pvalue of $0.003<0.05$ indicating the effect of price on buying interest is significant, so there is sufficient evidence to state that price has a significant effect and positive on buying interest. Thus, the first hypothesis 
in this study can be accepted. This finding is relevant to Bakti et al. (2020), which states that price positively affects buying interest at the Lazada online store in Lampung.

b. H2: Promotion has a positive effect on buying interest.

In the table above, the coefficient value is positive at 0.365 with a t-statistic value of $4.438>1.96$ and a pvalue of $0.000<0.05$ indicating the effect of promotion on purchase intention is significant, so there is sufficient evidence to state that promotion has a significant effect and positive on buying interest. Thus, the second hypothesis in this study can be accepted. This finding is in line with the findings of Dama (2016), which states that promotion has a significant effect on consumer buying interest at Lestari Computer Manado.

c. H3: Price has a positive effect on brand image.

In the table above, the coefficient value is positive at 0.401 with a t-statistic value of $3.664>1.96$ and a pvalue of $0.000<0.05$ indicating the effect of price on brand image is significant, so there is sufficient evidence to state that price has a significant effect and positive on brand image. Thus, the third hypothesis in this study can be accepted. This finding is relevant to Rifai et al.'s (2018) findings, which states that price affects the brand image of Ardiles shoe products in Surabaya, PT. Ardiles Cipta Wijaya.

d. H4: Promotion has a positive effect on brand image.

In the table above, the coefficient value is positive 0.298 with a t-statistic value of $2.820>1.96$ and a pvalue of $0.005<0.05$ indicating the effect of promotion on brand image is significant, so there is sufficient evidence to state that promotion has a significant effect and positive on brand image. Thus the fourth hypothesis in this study can be accepted. This finding strengthens the findings of Meiliani and Ferdinand (2015), which state that promotional attractiveness has a positive and significant influence on brand image.

e. $\quad$ H5: Brand image has a positive effect on buying interest.

Significant and positive on buying interest. Thus the fifth hypothesis in this study can be accepted. In the table above, the coefficient value is positive at 0.291 with a t-statistic value of $2.988>1.96$ and a $p$-value of $0.003<0.05$ indicating the effect of brand image on buying interest is significant, so there is sufficient evidence to state that brand image has an effect. This finding strengthens Febriyanti and Wahyuati (2016) findings, which state that brand image has a significant and positive effect on buying interest.

There are two indirect influence hypotheses tested in this study, namely:

a. H6: Price has a positive effect on buying interest mediated by brand image.

In the table above, the coefficient value is positive at 0.038 with a t-statistic value of $2.084>1.96$ and a pvalue of $0.117<0.05$, indicating that the indirect effect of price on buying interest through brand image is significant, so there is sufficient evidence for stated that brand image mediates significantly and positively the relationship between price and purchase intention. Thus, the sixth hypothesis in this study can be accepted. This finding supports Ghristian (2016) findings, which states that brand image has a positive and significant effect on buying interest in Levi's jeans in Surabaya.

b. H7: Promotion has a positive effect on buying interest mediated by brand image.

In the table above, the coefficient value is positive, which is 0.087 with a t-statistic value of $2.436>1.96$ and a p-value of $0.015<0.05$, indicating that the indirect effect of promotion on buying interest through brand image is significant, so there is enough evidence to state that brand image mediates a significant and positive relationship between promotion and purchase intention. Thus, the seventh hypothesis in this study can be accepted. This finding supports the findings of Armayani and Jatra (2019), which states that promotion significantly mediates the influence of brand image on purchasing decisions on Samsung smartphone products in the city of Denpasar.

\section{CONCLUSION}

Based on the data analysis and the findings and discussions described in the previous chapter, the following conclusions can be drawn:

1. Price has a significant and positive effect on buying interest. That is, if prices are more competitive, buying interest will increase, prices play an important role in consumer purchasing decisions, and in certain circumstances, consumers will be susceptible to price changes, so that if there is an increase or change in 
price, it can have an impact on reducing buying interest.

2. Promotion has a significant and positive effect on buying interest. That is, the higher the value and attractiveness of the promotion that is carried out, and the buying interest will increase, consumers will be interested in trying or buying a product if the product is offered with a good promotion so that if there is an increase in promotional activities, it can have an impact on increasing buying interest.

3. price has a significant and positive effect on brand image. That is, the higher the value of the brand image; the price determination is not dominant, companies that already have a strong brand image will not have obstacles if they want to increase product prices, consumers will accept if the product offered has a higher price than the price of other similar products if the product has a proven name and quality.

4. Promotion has a significant and positive effect on brand image. The higher the value of the promotion, the brand image will increase, so that if the promotion is carried out with the right strategy and continuously, it can strengthen the brand image. Promotion is not just a communication activity between companies and consumers; a good touch of communication can create a good brand image and ultimately have implications for increasing trust and consumer loyalty. Consumer trust in a brand begins with creating a positive image so that if the reputation of a brand image can be maintained and improved, it will create a top of mind when consumers think about a product that can ultimately have a direct impact on increasing buying interest.

5. Brand Image has a significant and positive effect on buying interest. The higher the value and quality of a brand image, the buying interest will increase. Brands make a product easier to recognize by consumers, and if the company already has a strong brand image, it will position the company in a separate class or market segment.

6. Price has a significant and positive effect on buying interest mediated by brand image. That is, brand image plays an essential role in the perception of cheap or expensive a product which can ultimately have an impact on buying interest, so to eliminate concerns about the price factor, the company must continue to improve a good image because of the brand image has been created well then the emphasis on price becomes reduce. To introduce the brand to potential customers, the company must run promotions consistently and continuously, which can ultimately increase branding in the eyes of consumers.

7. The promotion has a significant and positive effect on buying interest mediated by brand image. That is, appropriate and sustainable promotional activities will strengthen the brand image to have an indirect effect on buying interest. The consistency of promotions with different characteristics from competitors can create a brand image with its uniqueness.

The following are suggestions given based on the research that has been done, namely:

\section{Theoretical Suggestions}

a. For further research interested in developing this research, it is recommended to develop other variables related to buying interest that can have direct implications for purchasing decisions. In addition to developments outside of price, promotion, and brand image variables, it is recommended to add variables to the influence of government incentives policy on the development of electric cars and variables regarding after-sales service and resale value, and it is hoped that further research can develop electric cars for other brands besides Hyundai.

b. The limitations of this study are that it has not revealed all the factors that influence brand image and buying interest in electric cars. The coefficient of determination of brand image is only $42.2 \%$ which can be explained in this study, as well as the value of the coefficient of determination of buying interest-only amounting to $67.8 \%$, which can be explained in this study, meaning that there are about $57.8 \%$ of the brand image variable and $32.2 \%$ of the buying interest variable which can be explained from other variables outside the study so that further research is expected to be able to explore these variables.

c. The population of this study is the general public who live in Greater Jakarta; it is hoped that further research can expand the coverage area in population collection, and it is also recommended to increase the number of samples in the study so that it can better represent the actual situation.

d. This research was conducted during a covid-19 pandemic which did not allow researchers to do faceto-face with respondents, so researchers used google forms as a tool in collecting questionnaire data. It is 
recommended for further research to be in direct contact with respondents so that filling out questionnaires can be more accurate.

\section{Practical Suggestion}

a. Price has a positive effect on buying interest, and it is suggested that the company maintain a competitive benchmarking strategy by taking into account brand positioning. In determining the price, the company can also use a penetration pricing strategy, namely setting a lower price at the beginning to increase demand and market share. After that, the price can be increased gradually. Gradually. Please consider the discount strategy to maintain resale value. If the resale value can be maintained, it can be one of the advantages of Hyundai and increase consumer confidence in Hyundai products.

b. Promotions positively affect buying interest. It is recommended that currently running promotions are maintained, such as collaborating with Youtube influencers or other social media and can also involve the value chain so that consumers can feel they are getting the best.

c. Brand image has a positive effect on buying interest, and it is suggested that the company can strengthen its brand image because a strong brand image can create consumer loyalty. To increase brand awareness, Hyundai is advised to create jargon introduced in continuous advertisements or promotions so that consumers can never forget easily when they hear the Hyundai brand.

\section{REFERENCE}

[1] Alma, Buchari. (2016). Manajemen Pemasaran dan Pemasaran Jasa. Bandung: Alfabeta.

[2] Amanda, T., Winoto Tj, H., Kusniawati, A., \& Surjaatmadja, S. (2021). Effect of Electronic Word of Mouth, Product Quality, and Price on Purchase Intention. Budapest International Research and Critics Institute (BIRCIJournal): Humanities and Social Sciences. Vol. 4, No. 3. https://doi.org/10.33258/birci.v4i3.2424

[3] Amitay, Y., Winoto Tj, H., Saparso \& Wahyoedi, S. (2020). The Impact of Celebgram Endorsement on Purchase Intention: The Mediating Effect of Customer Attitude and Brand Awareness. $8^{\text {th }}$ International Conference on Entrepreneurship and Business Management (ICEBM) UNTAR.

[4] Armayani, A., \& Jatra, I. M. (2019). Peran Brand Image Memediasi Promosi dan Harga Terhadap keputusan Pembelian Smartphone Samsung di Kota Denpasar. E-Jurnal Manajemen, Vol. 8 No. 8: 5222-5239.

[5] Assauri, Sofjan. (2014). Manajemen Pemasaran: Dasar, Konsep, dan Strategi. Jakarta: PT Rajagrafindo Persada.

[6] Bakti, U., Hairudin, dan Alie, M. S. (2020). Pengaruh Kualitas Pelayanan, Produk dan Harga Terhadap Minat Beli Pada Toko Online Lazada di Bandar Lampung. Jurnal Ekonomi, Volume 22 Nomor 1, Pebruari 2020: 101118.

[7] Chin, W. W. (1998). The partial least squares approach to structural equation modeling. In G.

A. Marcoulides (Ed.), Modern methods for business research (pp. 295-358). Mahwah:

[8] Erlbaum

[9] Chin, W. W. (1998). The Partial Least Squares Approach to Structural Equation Modeling. In G.A. Marcoulides (Ed.), Modern Methods for Business Research (pp. 295-358). Mahwah, New Jersey: Lawrence Erlbaum Associates.

[10] Febriyanti, R. S. dan Wahyuati, A. (2016). Pengaruh Celebrity Endorser dan Brand Image Terhadap Keputusan Pembelian Melalui Minat Beli. Jurnal Ilmu dan Riset Manajemen, Volume 5 Nomor 5, Mei 2016: 1-18.

[11] Ferdinand, Augusty. (2014). Metode Penelitian Manajemen (Edisi ke-5). Semarang: Badan Penerbit Universitas Diponegoro.

[12] Ghristian, I. D. (2016). Pengaruh Harga Diskon, Kualitas Produk, Citra Merek, dan Iklan Terhadap Minat Beli Celana Jeans Levi's di Surabaya. Journal of Business and Banking, Volume 5 Number 2 November 2015 April 2016: 319-336.

[13] Ghozali, Imam dan Hengky Latan. (2015). Partial Least Square Konsep, Teknik dan Aplikasi Menggunakan Program SmartPLS 3.0 untuk Penelitian Empiris (Edisi ke-2). Semarang: Badan Penerbit Universitas Diponegoro.

[14] Hair, Joseph F., Black, W. C., Babin, B. J., \& Anderson, R. E. (2010). Multivariate Data Analysis (7 ${ }^{\text {th }}$ Ed). Englewood Cliffs: Prentice Hall.

[15] Hair, Joseph F., Hult, G. T. M., Ringle, C. M., \& Sarstedt, M. (2017). A Primer on Partial Least Squares Structural Equation Modeling (PLS SEM) $\left(2^{\text {th }}\right.$ Ed). Thousand Oaks: Sage.

[16] Henseler, J., Ringle, C. M., \& Sarstedt, M. (2015). A New Criterion for Assessing Discriminant Validity in Variance-based Structural Equation Modeling. Journal of the Academy of Marketing Science, 43(1): 115-135. 
[17] Hery Winoto Tj. (2020). Pengaruh Kualitas Produk dan Harga terhadap Keputusan Pembelian Minuman Bobba yang Dimediasi dengan Strategi Promosi. Syntax Literate: Jurnal Ilmiah Indonesia. Vol. 5, No. 12. http://dx.doi.org/10.36418/syntax-literate.v5i12.1875

[18] Keller, Kevin Lane. (2013). Strategic Brand Management: Building, Measuring, and Managing Brand Equity (4 ${ }^{\text {th }}$ Ed). England: Pearson Education.

[19] Lupiyoadi, Rambat. (2014). Manajemen Pemasaran Jasa Berbasis Kompetensi (Edisi ke-3). Jakarta: Salemba Empat.

[20] Meiliani, N. dan Ferdinand, A. T. (2015). Analisis Pengaruh Daya Tarik Desain Produk, Daya Tarik Promosi, dan Persepsi Kualitas Terhadap Citra Merek serta Dampaknya Terhadap Minat Pembelian Konsumen (Studi pada Calon Konsumen Honda Beat Pop di Dealer Nusantara Sakti Purwokerto). Diponegoro Journal of Management, Volume 5 Nomor 1, Tahun 2015: 1-11.

[21] Rifai, M., Retnowati, N., dan Noviandari, I. (2018). Pengaruh Iklan, Kualitas, dan Harga Terhadap Brand Image Sepatu Ardiles di Surabaya (Studi Kasus pada Pengunjung Cahaya Departement Store Surabaya). Jurnal Manajemen Branchmarck, Vol 4 Issue 1: 207-216.

[22] Rosita, R. (2016). Pengaruh Lokasi, Kelengkapan Produk, Kualitas Produk, Pelayanan, Harga, dan Kenyamanan Berbelanja terhadap Minat Beli Ulang Konsumen pada Lotte Mart Bekasi Junction. Jurnal Ilmiah Widya Ekonomika, Volume 1 Nomor 2 November 2016: 98-103.

[23] Sarstedt, M., Bengart, P., Shaltoni, A. M., \& Lehmann, S. (2017). The use of sampling methods in [24] advertising research: A gap between theory and practice. International Journal of Advertising, forthcoming.

[25] Sarstedt et al. (2017). The use of sampling methods inadvertising research: A gap between theory and practice. International Journal of Advertising, forthcoming.

[26] Tenenhaus, M., Amato, S. and Vinzi, V.E. (2004). A Global Goodness-of-Fit Index for PLS Structural Equation Modelling. Proceedings of the XLII SIS Scientific Meeting, 1, 739-742.

[27] Tjiptono, Fandi. (2019). Strategi Pemasaran: Prinsip dan Penerapan. Yogyakarta: Andi.

[28] Wahyoedi, S., Saparso, S., Tecoalu, M., \& Winoto Tj, H. (2021). The Effect of Service Quality, Learning Quality, and Promotion Strategy on Parents' Decisions in Choosing ABC Primary Schools. Budapest International Research and Critics Institute (BIRCI-Journal): Humanities and Social Sciences, 4(1), 999-1005. https://doi.org/10.33258/birci.v4i1.1701

[29] Websites:Indonesian Automobile Industry Data. (2021). Diakses pada 23 April 2021 dari https://www.gaikindo.or.id/indonesian-automobile-industry-data/.

[30] Indra. (2016). Peneliti: Energi Fosil Akan Habis 2050. Diakses pada 19 April 2021 dari https://www.antaranews.com/berita/545481/peneliti-energi-fosil-akan-habis-.

[31] Irle, Roland. (2020). Global Plug-in Vehicle Sales Reached over 3,2Million in 2020. Diakses pada 21 April 2021 dari https://www.ev-volumes.com/ 